\title{
LONG-TERM TRENDS IN CANCER MORTALITY IN THE REPUBLIC OF MOLDOVA
}

\author{
Olga PENINA
}

Nicolae Testemitanu State University of Medicine and Pharmacy, Republic of Moldova

Corresponding author: Olga Penina, e-mail: olga.penina@usmf.md

DOI: $10.38045 /$ ohrm.2021.4.07

CZU: [314.424:616-006](478)

Keywords: mortality rate, cancer, Republic of Moldova.
Cuvinte cheie: mortalitate, cancer, Republica Moldova.
Introduction. Cancer is the second cause-of-death mortality pattern in the Republic of Moldova. The study of both cancer mortality by age and its detailed causes is an important tool for evidence-based public health policy. The study aims at comparing recent changes in cancer mortality with long-term trends, depending on specific causes and age.

Material and methods. This study was carried out on the reconstructed 1965-2018 death time series, according to the 10th revision of the International Classification of Diseases. Standardized death rates were computed.

Results. After a gradual increase in the '70s and '80s of the last century, cancer mortality rate showed "reversed" patterns and started to decline in the '90s. This decline was due to the data quality issue and to the competing risks of dying from other causes sensitive to the social and economic circumstances of the '90s. Since the beginning of the millennium, cancer mortality has resumed its growth that continues up to now. Despite the increasing overall trend in cancer mortality rate during 1965-2018, the analysis by age and specific causes revealed opposite trends.

Conclusions. The malignant neoplasms specific for certain sites and age groups (stomach, uterus, leukaemia in children) showed, however some therapeutic progress, while the situation for other tumour sites (lung, breast, and intestine) worsened significantly. The moderate decrease in lung cancer in the 1990s should be cautiously interpreted.

\section{TENDINȚELE DE LUNGĂ DURATĂ ALE MORTALITĂȚII PRIN CANCER ÎN REPUBLICA MOLDOVA}

Introducere. Cancerul ocupă locul al doilea în structura mortalității pe cauze de deces în Republica Moldova. Analiza mortalității pe vârste și cauze detaliate de deces este un instrument important în politica de sănătate publică bazată pe dovezi. Scopul studiului este de a contrasta schimbările recente ale mortalității prin neoplasme, cu tendințele sale pe termen lung, în funcție de cauza detaliată și de vârstă.

Material și metode. În acest studiu, ne bazăm pe seriile de timp ale mortalității pentru anii 1965-2018, reconstruite în termenii celei de a 10-a revizuiri a Clasificării Internaționale a Maladiilor, fiind calculate ratele standardizate ale mortalității.

Rezultate. După creșterea treptată în anii '70 și '80 ai secolului trecut, tendința mortalității prin cancer s-a inversat și a început să scadă în anii '90. Atribuim acest declin problemei calității datelor și riscurilor concurente, de a deceda prin alte cauze mai sensibile la circumstanțele sociale și economice din anii '90. De la începutul mileniului, mortalitatea prin neoplasme și-a reluat creșterea, care continuă până în prezent. Deși tendința generală a mortalității prin cancer în anii 1965-2018 este una ascendentă, analiza în funcție de vârstă și de cauză detaliată a relevat tendințe opuse.

Concluzii. Pentru neoplasmele maligne ale anumitor localizări și grupe de vârstă (stomac, uter, leucemie la copii) s-au realizat unele progrese, în timp ce pentru alte localizări (plămân, sân și intestin) situația s-a agravat semnificativ. Declinul moderat al mortalității prin cancer pulmonar din anii '90 trebuie interpretat cu prudență. 


\section{INTRODUCTION}

The problem of high mortality among the adult population in the former Soviet Union (FSU) countries is well known $(1,2)$. For these countries, especially those of the European part of the FSU, as Ukraine or Russia, high mortality from diseases of the circulatory system and deaths due to injury and poisoning account for much lower values of life expectancy at birth as compared to Western countries (3) where a continuous population health progress has been recorded since the 1970s mostly due to a spectacular cardiovascular mortality decline known as cardiovascular revolution (4). Furthermore, in the high-income western countries, a decrease in mortality from cancer, which is the leading cause of death there at present, has been reported over the last two decades. This recent improvement was mainly due to favourable mortality trends in the commonest specific cancers, while liver cancer in both sexes and lung cancer in females constitute a priority for prevention (5).

Previous studies on mortality trends in the Republic of Moldova have identified a serious health decline among the adult population since the mid1960 s, though accompanied by recent modest improvement, especially among the female population $(6,7)$. Nevertheless, the current life expectancy at birth is the same as in the mid-60s of the last century in males (65.8 years in 1965 and 65.9 years in 2020), while females live less than four years over the last 55 years (70.1 years in 1965 and 73.8 years in 2020). The lack of therapeutic progress in males and the slight improvements in females are completely lower than the results achieved across the western countries (more than 11 years in France or even 15 years in Japan). The stagnation of life expectancy in Moldova is explained by a continuous increase in adult mortality from non-communicable diseases, the cardiovascular diseases being the first and foremost among all deaths due to injury and poisoning, which was partially compensated by a decrease in infant and child mortality. In addition, the burden of digestive diseases, and particularly the liver cirrhosis, absolutely worsens the situation, especially among females whose life expectancy, both during the Soviet period and after the independence proclamation, was gradually decreasing as compared to other FSU countries (8). Furthermore, the considerable half-century increase in mortality due to cardiovascular disease or injury and poisoning dropped down as a result of the 1985 anti-alcohol campaign and the severe socioeconomic crisis of the 1990s occurring across the country after the USSR collapse. These short-term rises and falls and the relatively stable tendency in the overall cancer mortality, especially in females, were followed however by a steady increase since the late 1990s. The latter period differs from the situation recorded in other FSU countries, as for example, the cancer death rate in Russia has revealed a decreasing tendency since the mid-1990s, which continues up to now, being mostly associated with lung cancer in males and stomach cancer (9).

Although cardiovascular mortality in Moldova has often been researched $(7,10)$, less attention was paid to long-term cancer mortality trend. It is mainly explained by methodological issues. The problem is that the long-term studies encounter temporal discontinuities induced by the periodic changes in the classification of death causes. The solution is to analyse the death time series reconstructed by a special method proposed by Meslé and Vallin (11). This method of reconstruction allowed studying the continuous series of deaths described by the $10^{\text {th }}$ revision of the International Classification of Diseases and Causes of Death (ICD-10) during the 1965-2018 period, and which are available within the Human Cause-of-Death Database providing background documentation (https://www.causesofdeath.org/cgi-bin/main. php).

The study aims at comparing the recent changes in cancer mortality to their long-term trends by detailed cause and age. The hypothesis of this research is that the cancer mortality trends according to age and detailed causes do not reflect the overall cancer mortality trend; moreover, certain temporal changes may refer to the data quality issues and to the competing life-threatening risks.

\section{MATERIAL AND METHODS}

This present research was based on the cause-ofdeath time series for the Republic of Moldova reconstructed by the author (12) and published in The Human Cause-of-Death Database (HCD) over 1965-2014 years (13) and extended up to 2018 (Penina, unpublished). Mortality data for the 2015-2018 period were provided by the National Agency for Public Health (NAPH). 
As regarding the Republic of Moldova, the mortality data were reconstructed based on the 10th Revision of the International Classification of Diseases and Causes of Death (ICD-10). The HCD included the detailed list of causes of death that comprises 211 items. The mortality data for Moldova and presented in the HCD were revised due to some data quality issues regarding the older ages and infancy, which were especially recorded in the 1960s and 1970s. Moreover, the death rate due to ill-defined causes of death (items R00-R99 under ICD-10), including "Senility" (R54 under ICD-10), were reassessed by a special method among other causes of death (found in the HCD background documentation for Moldova).

The annual intercensal estimation data on population during the period 1965-2004 were retrieved from the HCD. For 2004-2014, we used the annual intercensal estimates performed by the author (Penina, unpublished). Finally, the official post-census population estimates for 20152018 were used as referring to common resident population (14).

The direct method of standardization based on the 2013 European standard population was used (15). Age-specific death rates were also standardized by the direct method. The $95 \%$ confidence limits were computed based on Byar's or exact CI method (16). All the studies were analysed via the R software.

Table 1 presents the list of death causes used in the study with the corresponding codes, according to the detailed list of death causes used in the HCD and ICD-10. Ill-defined causes of death (items 193, 194 under the HCD list and R00-R99 under ICD-10).

Table 1. List of death causes included in the study and their corresponding codes based on the detailed list in the Human-Cause-of-Death Database (HCD) and the 10th revision of the International Classification of Diseases and Causes of Death (ICD-10).

\begin{tabular}{|c|c|c|}
\hline Causes of death & HCD detailed list & ICD-10 codes \\
\hline 1. Infectious diseases & $1-47$ & A00-B99 \\
\hline 2. Neoplasms, including: & $48-79$ & C00-D48 \\
\hline Upper aerodigestive tract cancers & $48-49$ & C00-C15 \\
\hline Stomach cancer & 50 & $C 16$ \\
\hline Colon cancer & $51-53$ & $C 17-C 21$ \\
\hline Liver cancer & 54 & $C 22$ \\
\hline Cancer of pancreas & 55 & $C 25$ \\
\hline Gastrointestinal cancers & 56 & $C 23, C 24, C 26$ \\
\hline Respiratory system cancer & $57-59$ & C30-C34, C37-C39 \\
\hline Breast cancer & 63 & C50 \\
\hline Uterus cancer & 64,65 & C53-C55 \\
\hline Female genital cancers & 66,67 & C51, C52, C56-C58 \\
\hline Male genital cancers & 68,69 & C60-C63 \\
\hline Urinary tract cancer & 70,71 & C64-C68 \\
\hline Brain cancer & 72 & C70-C72 \\
\hline Cancer of lymphoid, haematopoietic tissue & $75-78$ & C81-C96 \\
\hline Other neoplasms & $60-62,73-74,79$ & C40-C49, C69, C73-C80, C97, D00-D48 \\
\hline 3. Diseases of the circulatory system & $101,106-128$ & G45, I00-I99 \\
\hline 4. Diseases of the respiratory system & $129-143$ & J00-J98, U04 \\
\hline 5. Diseases of the digestive system & 144-158 & K00-K93 \\
\hline 6. External causes & $195-211$ & V01-Y98 \\
\hline 7. Other diseases and death causes & $\begin{array}{c}80-100 \\
102-105 \\
159-192\end{array}$ & $\begin{array}{l}\text { D50-G44, } \\
\text { G47-H95, } \\
\text { L00-Q99 }\end{array}$ \\
\hline All causes & $1-211$ & $A 00-Y 98$ \\
\hline
\end{tabular}

Source: (13) 


\section{RESULTS}

At present, neoplasms rank second among other mortality patterns from Moldova for both sexes, and the total mortality rate ranging between $8 \%$ $18 \%$ in 1965-2018 (fig. 1). For both sexes, neoplasms were ranked third in the 1970s following the respiratory diseases. Due to a significant lower mortality rate from the latter cause in the 1980s, neoplasms ranked second, constantly competing with other leading causes of death. Among males, cancer mortality had the same incidence as the external causes of death in the late 1970 s and the early 1980 s or respiratory diseases and digestive diseases by the mid-1980s. Since 2000 , however, there has been a considerable difference between neoplasms and the three aforementioned main groups of death causes due to a steady increase in cancer mortality. Since the early 1980s, neoplasm mortality among females, has constantly competed with the digestive diseases until 2000 , followed by the same difference in occurrence as in males. In the mid-1980s, just before the Gorbachev's anti-alcohol campaign, neoplasms lost the second place in favour of the digestive diseases, which showed a fulminant development.

After the stagnation of the mortality rate in the 1970 s and its increase in the 1980s, the trend in cancer mortality has reversed and started to decline in the 1990s. Since the beginning of the millennium, the trend in cancer mortality has resumed its growth and continues so far. The increase in mortality in the 1980 s, followed by the decline in the 1990s and, finally, the subsequent growth since 2000 is much more common in men than for women. In males, cancer mortality exhibited a twofold increase between 1969 with the minimum value recorded $(193.5,95 \%$ CI 181.6205.9) and 2018 with the maximum registered one (402.7, 95\% CI 388.0-417.8). In 2016, the increase between the minimum value in 1972 (127.3, 95\% CI 120.3-134.5) and the maximum one (207.5, 95\% CI 199.3-216.0) was 1.6 times among females.

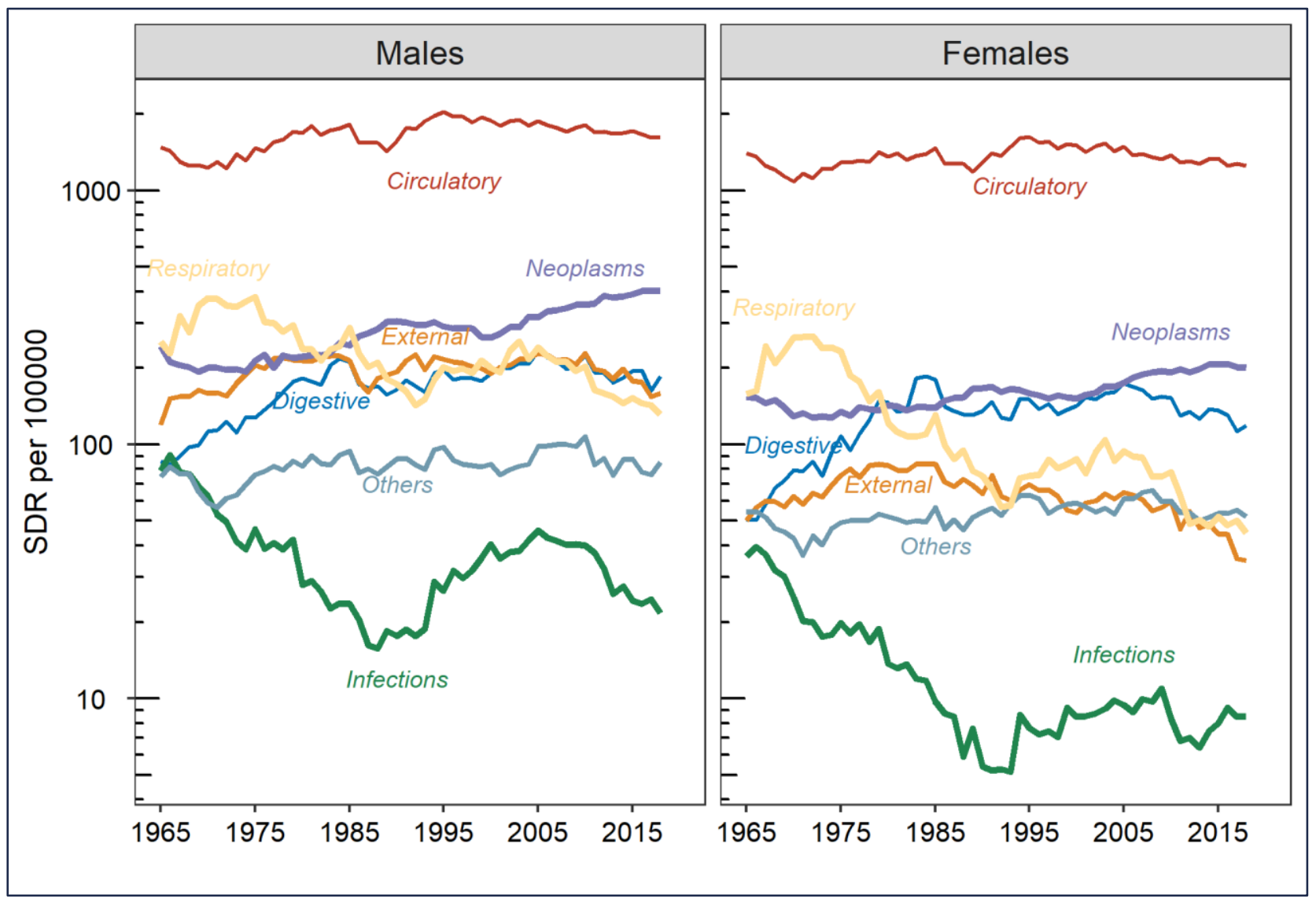

Figure 1. Standardized number of deaths for seven leading causes of death in the Republic of Moldova, 1965-2018, by sex (per 100000). Semilogarithmic scale.

Source: author's calculations based on HCD Database, NAPH, and NBS. 
Cancer mortality occurrence varies considerably depending on age. There has been a constant decrease among children since 2000. Cancer mortality among young adults (15-39 years old) is maintained at the same level throughout the period without any significant difference in genders. The adults (40-64 years old) and the elderly (60 years old and older) show a more pronounced difference in genders. Among mature adult men, the increase in cancer mortality before the 1990s was by far greater than it has been since 2000 (respectively, 1.6 times in 1965-1990 and 10\% increase in 2000-2018). Among older men, the situation is reversed. For this age group, the growth observed from 2000 (twofold increase in 2000-2018) is higher compared to the Soviet period (1.5 times in 1965-1990). In addition, the decline in mortality from neoplasms in the 1990s was more marked in older males than in mature male adults. Cancer mortality among females aged 40 64 years stagnated throughout the study period. Lastly, among older women, the trend in neoplasm mortality is very similar to that among older males. The decrease in old-age mortality in the 1960 s is most likely associated with data quality problems such as age heaping and should be interpreted with caution (fig. 2).

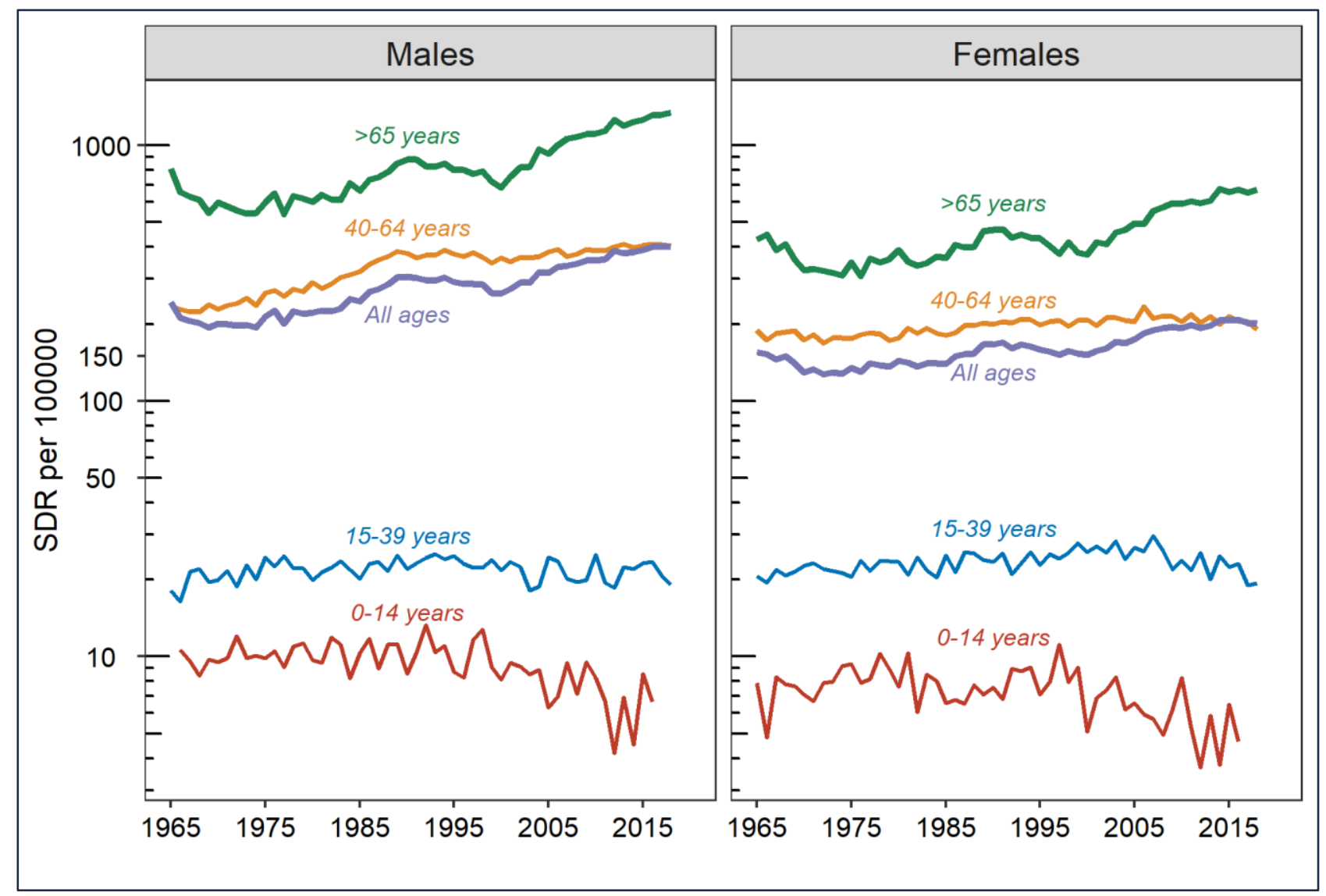

Figure 2. Standardized death rates from neoplasms by main age groups in the Republic of Moldova, 1965-2018, by sex (per 100000). Semilogarithmic scale.

Source: author's calculations based on HCD Database, NAPH, and NBS.

Mortality analysis by detailed cause of death provides a better understanding of the overall trend in cancer mortality. For simplicity, we provide an analysis of cause-specific cancer mortality for all ages and both sexes. It is clear that some cancer sites, such as breast cancer, are closely or exclusively associated with gender. Figure 3 shows trends in standardized death rates from neoplasms of different locations, except for neoplasms of the genitourinary system and genital organs presented in figure 4. Cancer of the respiratory system and colon cancer are the two leading causes and account for one-third of all deaths from malignant neoplasms in both sexes. Mortality from malignant neoplasms of the digestive system varies widely by location (fig. 3 , panel 
A). Death rates from malignant neoplasms of the intestine continuously increased and more than tripled between 1965 and 2018 (from 12.2 in 1965 to 43.6 in 2018). The share of this cause of death in total cancer mortality increased from $7.0 \%$ to $16 \%$ over the entire period. Concomitantly, the standardized indicator for stomach cancer reduced twice between 1965 and 2018 (from 42.4 in 1965 to 19.3 in 2018), declining from $23 \%$ to $7.0 \%$. Mortality from liver cancer and cancer of the pancreas has traced a rising trend, so that at present, malignant neoplasms of these two sites have reached the stomach site. Finally, other malignant neoplasms of the digestive system have showed a downward trend since the early 1990s.

Mortality from cancer of the respiratory system largely represented by lung cancer determines the overall upward trend in cancer mortality and its decline in the 1990s (fig. 3, panel B). The risk of dying from lung cancer increased at a particularly rapid rate during the Soviet period (from 25.4 in 1965 to 48.0 in 1990), while in the 21st century, the growth has slowed down but still continued (from 37.0 in 2000 to 50.1 in 2018). Although the contribution of upper aerodigestive tract cancer (lip, oral cavity, pharynx, and oesophagus) to the overall cancer rate is not as large (6\% in 2018), neoplasms of this site increased by three times during the whole period. As for neoplasms of the respiratory system, cancer mortality of this location rose especially quickly until the mid1990s, while during the subsequent years, this remained at the same level.

Mortality from Leukaemia and lymphomas demonstrated a moderate $40 \%$ increase throughout the overall period for both males and females (from 9.4 in 1965 to 13.0 in 2018). Although we analysed cause-specific mortality for all ages, it is important to note that among children, some progress in reducing mortality from leukaemia and lymphomas has been made in recent years. These achievements explain the recent declining trend in overall cancer mortality among children. The situation with mortality from malignant neoplasms of the brain deteriorated rapidly over the last twenty years, and this unfavourable trend seems to continue in the future. Finally, the residual group other neoplasms is mostly presented by malignant neoplasms of other and unspecified sites ( $70 \%$ in 2018 , both sexes). A relatively large contribution of neoplasms of the unspecified loca tion reveals the problems associated with clinical differentiation and codification of causes of death in the country.

Breast cancer followed a growing tendency for the study period, with standardized death rates increasing 2.5 times between 1965 and 2018. Mortality from uterus cancer, on the contrary, declined, especially quickly in the 1970s and 1980s; however, since the mid-1980s, this progress has ceased. These contrasting trends in breast and uterus cancer mortality, which occurred in Moldova like in all the industrial countries, resulted in a crossover between these two conditions in the early 1980s. Mortality from cancer of other female genital organs did not change considerably throughout the whole period. Cancer of male genital organs mostly presented by prostate cancer has had an increasing tendency accelerated since the early 1990s. Cancer of the urinary system dominated by bladder cancer followed the longterm upward trend throughout the whole period we studied (fig. 4).

\section{DISCUSSIONS}

The problem of under-registration of cancer mortality in the FSU countries and its unusual decline in the 1990s contrasted to a huge upsurge in cardiovascular mortality and deaths from injury and poisoning found in the literature. There are many researches on the European part of the FSU (Russia, Ukraine, Belarus, the Baltic countries). Shkolnokov et al. (17) studied cancer mortality in Russia and Ukraine and suggested a number of hypotheses that could explain the observed rapid increase in the 1980s followed by a marked decline in the 1990s. The authors provide evidence of a significant under-recording of cancer deaths among the elderly, especially in rural areas, and changes in coding practices in the 1980s. In November 1984, the Ministry of Public Health of the USSR issued Order 1300 to improve the system of cause-of-death registration. Furthermore, the active development of a territorial network of cancer dispensaries in the former republics, including Moldova, at that time could intensify attention to the problem of cause-of-death registration and partially contribute to the growth of cancer mortality at older ages in the 1980s.

In March 1989, the Ministry of Public Health introduced more radical changes in coding practices, which caused a huge growth in the number 


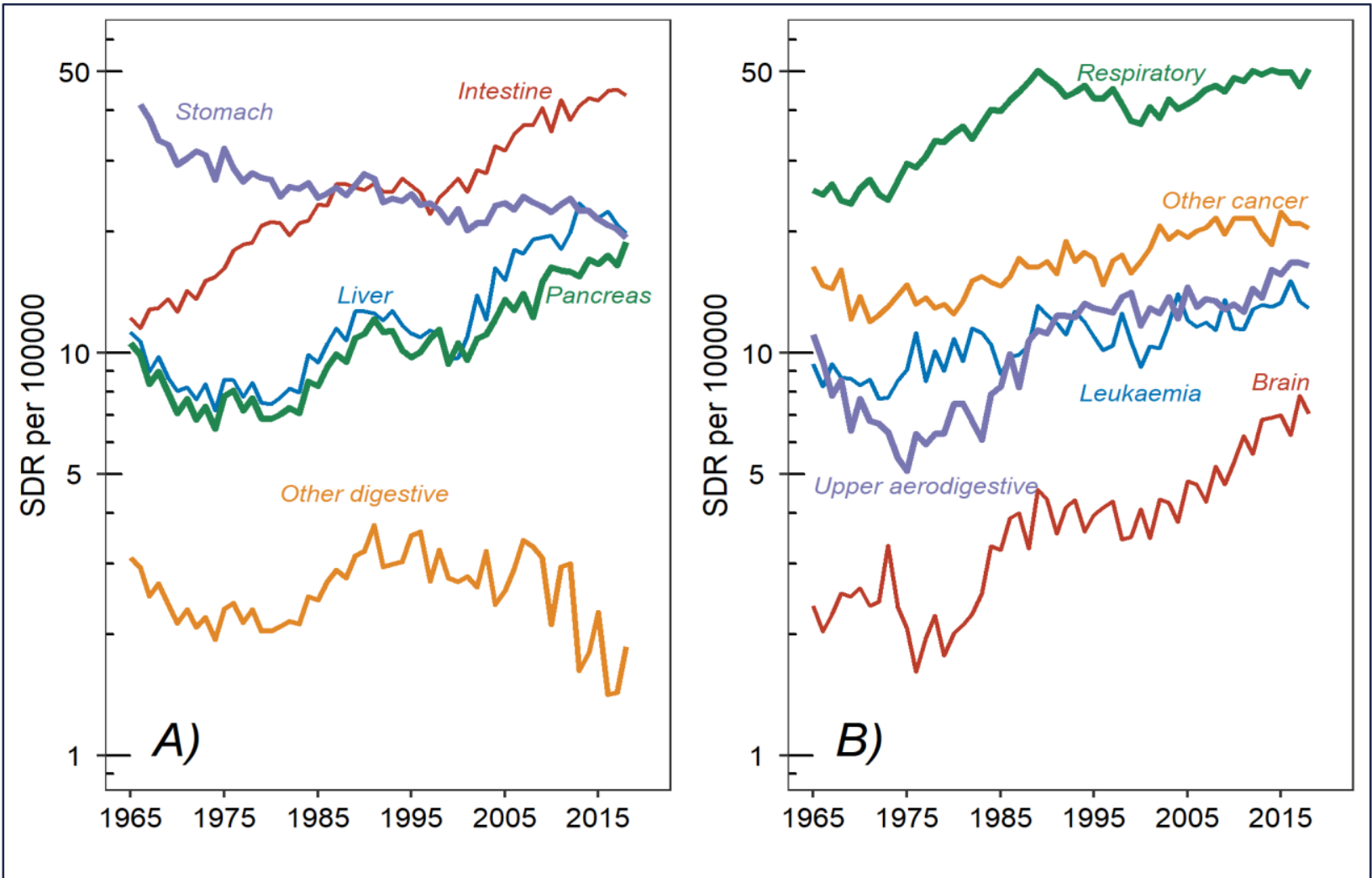

Figure 3. Standardized death rates from neoplasms (without cancer of genital organs and cancer of the genitourinary system) in the Republic of Moldova, 1965-2018, both sexes, all ages (per 100000). Semilogarithmic scale.

Source: author's calculations based on HCD Database, NAPH, and NBS.
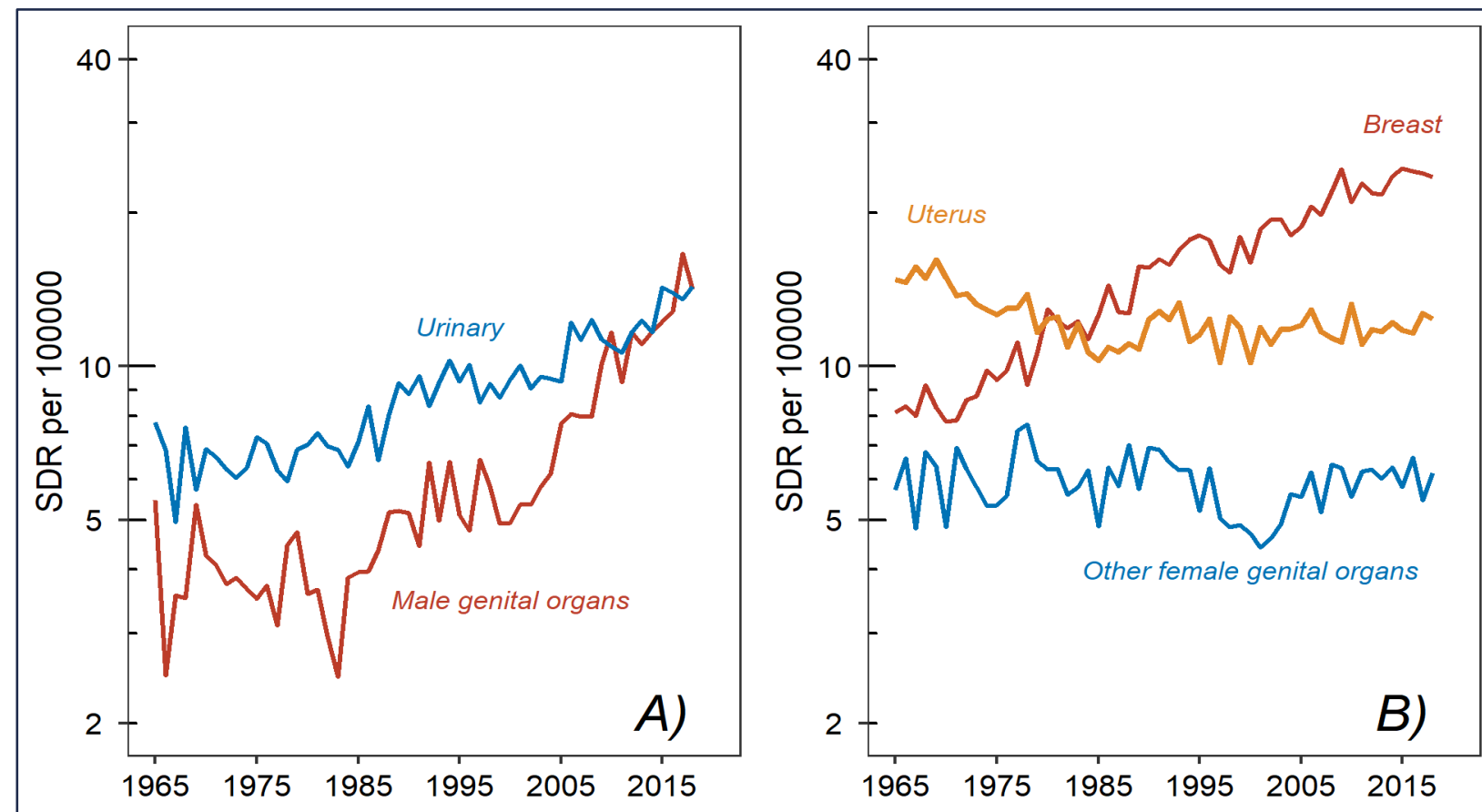

Figure 4. Standardized death rates from cancer of genital organs and the urinary system in the Republic of Moldova, 1965-2018, all ages, both sexes (per 100000). Semilogarithmic scale.

Source: author's calculations based on HCD Database, NAPH, and NBS. 
of deaths from "Senility" in the former USSR republics.

According to this directive, if malignant neoplasm co-existed with cardiovascular disease, the former had to be registered as an underlying cause of death. These changes in coding practices in the 1980 s and a return to a previous registration custom in the 1990s may serve as a plausible explanation of the increase in cancer mortality among the elderly in the 1980s and its decline in the 1990s. The same authors attribute some reduction in male mortality from cancer in middle age groups in the 1990s to a combination of a cohort effect and a simultaneous sharp rise in mortality from competing causes of death like cardiovascular diseases and accidents.

A higher proportion of the rural population in Moldova as compared to other European ex-Soviet republics may partially lead to a higher proportion of under-registered cancer deaths among the elderly in the 1960s and 1970s. The comparative analysis of life expectancy and causes of death between Moldova and Ukraine (18) demonstrated a lower level of cancer mortality in Moldova, especially among men, in the 1960s and 1970s. The gradual improvement in cancer registration and increased societal attention to this issue, particularly in the aftermath of the Chernobyl disaster in 1986, may account for part of the increase in cancer mortality in the 1980s.

In Moldova, as in Ukraine or Russia, cancer mortality declined steadily in the 1990s, contrasting with large fluctuations in mortality caused by cardiovascular diseases and deaths from injury in the late 1980s and the 1990s. The absolute insensitivity of cancer mortality to the social and economic upheavals of this period demonstrated for Moldova was previously observed for other countries of the ex-USSR $(19,20)$. In the case of Moldova, the decline in overall cancer mortality in the 1990 s is primarily attributed to lung cancer. To explain this mortality reversal, we assume the hypothesis on competing risks earlier proposed by Shkolnokov et al. to explain the same phenomenon, at least partially, in Russia and Ukraine. We suggest that the rapid growth of mortality from diseases of the circulatory system and accidents caused by the economic and the social crisis of the 1990s in the country increased the risk of dying from these causes among people suffering from cancer $(17,21)$. Indeed, after the end of the economic decline of the 1990s, Moldovan trend in male mortality from lung cancer resumed its slow growth that persists up to now. Furthermore, changes in coding practice along with the growth in the number of deaths from "senility" may also be partly responsible for the decrease in cancer mortality in the 1990s. In Moldova, deaths classified under senility were redistributed by a special method between diseases of the cardiovascular system before the analysis (22).

Similar dynamics in mortality due to lung cancer and other tobacco-related neoplasms among adult males can be observed, for example, in Ukraine and Russia. In Moldova, like in other exSoviet countries, the period of growth is directly linked to the spread of tobacco consumption, as well as to the environmental pollution triggered by the rapid development of the industry and agriculture at that time. However, the economic recession in the late 1980s in the former USSR followed by the economic crisis in the newly independent states reduced the industrial and agricultural pollution and tobacco consumption habits in these countries (20).

The lack of progress in mortality from uterus cancer since the mid-1980s and its rapid growth for breast cancer are mainly attributed to insufficiently-organized screening programmes and inadequate diagnostic capacities. Thus, according to the recent population-based study in ten FSU republics, Moldova and Armenia have the largest proportion of cervical cancer $(>50 \%)$ diagnosed at late stages (II-IV) (23).

The contrasting trends in mortality from stomach and colon cancers described in Moldova and other developed countries refer to the changes in traditions of food preparation and eating habits. Thus, declining mortality from stomach cancer is closely associated with the increased food variety in a diet, while the rise in mortality from cancer of the intestine is positively correlated with the consumption of meat and animal fat (24). In Moldova, as in other countries of the FSU, this phenomenon has showed an enormous delay compared to Western countries. 


\section{CONCLUSIONS}

1. Despite the increasing trend in overall cancer mortality during 1965-2018, the analysis of deaths by age and specific causes revealed opposite trends. Certain malignant neoplasms (originating in stomach, uterus, leukaemia in children) showed some progress, while the occurrence of other cancers (lung, breast, and intestine cancer) significantly worsened. This requires the strengthening of appropriate preventive measures.

2. The moderate decline in mortality from lung cancer in the ' 90 s should be interpreted with caution. This can refer to the changes in the coding practice of causes of death and to the competing lifethreatening risks from the causes that were more sensitive to the social and economic conditions of the 1990s, such as cardiovascular diseases and deaths from injury and poisoning.

\section{CONFLICT OF INTERESTS}

The author declares no conflict of interest at.

\section{REFERENCES}

1. Meslé F, Vallin J. The End of East-West Divergence in European Life Expectancies? An Introduction to the Special Issue. Eur J Popul. 2017;33(5):615-27.

2. Grigoriev P, Shkolnikov VM, Andreev E, et al. Mortality in Belarus, Lithuania, and Russia: Divergence in Recent Trends and Possible Explanations. Eur J Popul Rev Eur Démographie. 2010;26(3):245-74.

3. Vishnevsky A. Mortality in Russia: the second epidemiological revolution that never was. Demographic Review. 2015;2(5):4-33.

4. Vallin J, Meslé F. Convergences and divergences in mortality: A new approach of health transition. Demogr Res. 2004;S2:11-44.

5. Hashim D, Boffetta P, La Vecchia C, et al. The global decrease in cancer mortality: trends and disparities. Ann Oncol. 2016;27(5):926-33.

6. Gagauz O, Stratan A, Buciuceanu-Vrabie M, Penina O. Raportul privind analiza situației populației în Republica Moldova. Chișinău: INCE al AȘM; 2016. Available from: https://moldova.unfpa.org/ro/ publications/raportului-privind-analiza-situa\%C8\%9Biei-popula\%C8\%9Biei

7. Penina $\mathrm{O}$, Raevschi E. Mortalitatea cardiovasculară și speranță de viață în Republica Moldova. Bul Acad Stiinţe Mold Stiințe Medicale. 2020;1 (65)):171-7.

8. Penina 0. Alcohol-Related Causes of Death and Drinking Patterns in Moldova as Compared to Russia and Ukraine. Eur J Popul. 2017;33(5):679-700.

9. Zaridze DG, Kaprin AD, Stilidi IS. Dynamics of morbidity and mortality from malignant tumors in Russia. Vopr Onkol. 2018;64:578-91.

10. Raevschi E. Mortalitatea cardiovasculară prematură în Republica Moldova. Chisinau: Elan Poligraf Printing House; 2017.

\section{ACKNOWLEDGMENT}

The study was carried out within the framework of the Research Project 21.00208.8007.02/PD "Disparitățile socio-demografice și regionale ale mortalității în Republica Moldova [Socio-demographic and regional disparities in mortality in the Republic of Moldova]".

11. Meslé F, Vallin J. Reconstructing Long-Term Series of Causes of Death. The Case of France. Hist Methods J Quant Interdiscip Hist. 1996;29(2):72-87.

12. Penina 0. Reconstruction of the continuity of cause-specific mortality trends for the Republic of Moldova. Econ Şi Sociol. 2015;(2):70-7.

13. HCD Database. The Human Cause-of-Death Database. Hum Cause-Death Database. 2019; [cited 2019 Oct 29] Available from: https:// www.causesofdeath.org/cgi-bin/main.php

14. National Bureau of Statistics of Moldova. Usual resident population, as of January 1 by Years, Areas and Sex. Banca Date Stat. 2021; [cited 2021 Jun 29] Available from: https://statbank.statistica.md:443/PxWebPxWeb/pxweb/en/20 Populatia si procesele demografice/20 Populatia si procesele demografice_POPrec_POP010/POP0101 00rcl.px/

15. European Commission. Revision of the European Standard Population - Report of Eurostat's task force - 2013 edition. Luxembourg: Publications Office of the European Union; 2013. 128 p. [cited 2021 Aug 22] Available from: https://ec.europa.eu/eurostat/web/products-manuals-andguidelines/-/KS-RA-13-028

16. Altman DG, Machin D, Bryant TN, Gardner MJ, editors. Statistics with confidence: confidence intervals and statistical guidelines. 2. ed. London: BMJ; 2000.

17. Shkolnikov VM, McKee M, Vallin J, et al. Cancer mortality in Russia and Ukraine: validity, competing risks and cohort effects. Int $J$ Epidemiol. 1999;28(1):19-29.

18. Penina O. Prodolzhitel'nost' zhizni i prichiny smerti v Moldove, Ukraine i Rumynii [Life expec 19. 
tancy and causes of death in Moldova, Ukraine and Romania]. Proceedings International Conference Demographic Development: Challenges of Globalization. Moscow: MAKS Press; 2012. p. 386-91.

20. Grigoriev P. Health crisis in Belarus as reflected by cause-of-death and regional mortality trends and patterns. 2012; Available from: http://www.demogr.mpg.de/publications\%5Cfiles\%5C4656 1350046430_1_Grigoriev\%20Health\%20Crisis\%20in\%20Belarus\%20Dissertation.pdf

21. Meslé F, Vallin J. Mortality and Causes of Death in 20th-Century Ukraine. Dordrecht: Springer Netherlands; 2012. 279 p. Available from: https:// link.springer.com/book/10.1007\%2F978-94007-2433-4

22. Shkolnikov VM, McKee M, Leon D, Chenet L. Why is the death rate from lung cancer falling in the Russian Federation? Eur J Epidemiol. 1999;15(3): 203-6.

23. Penina O. About the Republic of Moldova Data on Causes of Death. https://www.causesofdeath.org: INED, MPIDR; 2016. [cited 2016 May 12] Available from: http://causesofdeath.org/Data/ MDA/ 20160121/MDA_bd.pdf

24. Ryzhov A, Corbex M, Piñeros $M$, et al. Comparison of breast cancer and cervical cancer stage distributions in ten newly independent states of the former Soviet Union: a population-based study. Lancet Oncol. 2021;22(3):361-9.

25. Meslé F. Cancer et alimentation: le cas des cancers de l'intestin et du rectum. Population. 1983; 38(4):733-62.

Date of receipt of the manuscript: 30/06/2021

Date of acceptance for publication: 27/09/2021

Olga PENINA, ORCID ID: 0000-0002-3884-2751, Web of Science Researcher ID: AAP-4946-2020, SCOPUS Author ID: 37862005100 